\title{
MAKNA TRI TANGTU DI BUANA YANG MENGANDUNG ASPEK KOMUNIKASI POLITIK DALAM FRAGMEN CARITA PARAHYANGAN
}

\author{
Rangga Saptya Mohamad Permana \\ Komunitas Pecinta Naskah Sunda Kuno
}

\begin{abstract}
ABSTRAK
Dahulu, di Kerajaan Sunda berlaku sistem pemerintahan yang unik, yang disebut Tri Tangtu di Buana. Penelitian ini bertujuan untuk mengungkap makna Tri Tangtu di Buana yang mengandung aspek komunikasi politik dalam Fragmen Carita Parahyangan. Penelitian ini menggunakan metode analisis hermeneutik Paul Ricoeur. Data penelitian diperoleh dari teks naskah Sunda kuno Fragmen Carita Parahyangan. Berdasarkan hasil penelitian terhadap teks naskah Sunda kuno Fragmen Carita Parahyangan diketahui bahwa secara umum, Tri Tangtu di Buana yang terdiri dari prebu, rama, dan resi di dalam naskah Sunda kuno Fragmen Carita Parahyangan ini merupakan tiga lembaga yang secara bersamaan memegang jabatan di pemerintahan Kerajaan Sunda; ketiganya memiliki hak dan kewajiban yang berbeda dalam memimpin Kerajaan Sunda, yang di dalamnya mengandung aktivitas komunikasi politik dalam dua peristiwa, yaitu peristiwa pembagian kekuasaan dan pembagian wilayah kekuasaan.
\end{abstract}

Kata-kata kunci: Makna, teks, komunikasi, politik, kekuasaan

\section{CONTAIN OF POLITICAL COMMUNICATION ASPECTS IN THE MEANING OF TRI TANGTU DI BUANA IN THE FRAGMEN OF CARITA PARAHYANGAN}

\begin{abstract}
In the past, Sundanese Kingdom applied a unique system of governance, which is called Tri Tangtu di Buana. This study aims to reveal the meaning of Tri Tangtu di Buana containing political communication aspects in Fragment of Carita Parahyangan. This research uses Paul Ricoeur's hermeneutic analysis method. Data were obtained from the text of ancient Sundanese manuscript Fragment of Carita Parahyangan. The result shows that Tri Tangtu di Buana consist of prebu, rama, and resi are three institutions that simultaneously hold the leadership roles in Sundanese Kingdom; these three institutions have different rights and obligations, which contains the activities of political communication in two events of distribution of power and territory.
\end{abstract}

Keywords: Meaning, text, communications, politics, power

Korespondensi: Rangga Saptya Mohamad Permana, M.I.Kom. Komunitas Pecinta Naskah Sunda Kuno. J1. Moch Yusuf No.23 Cilengkrang Kabupaten Bandung 40620, Indonesia. Email: ranggasaptyamp@gmail.com 


\section{PENDAHULUAN}

Sejak dahulu, masyarakat Sunda telah memiliki tiga kelembagaan yang masingmasing memiliki tugas yang berbeda satu sama lain. Tiga kelembagaan tersebut memiliki kekuasaan dalam bidangnya masing-masing. Model pembagian/pemisahan kekuasaan tradisional masyarakat Sunda beserta aturanaturan lainnya cukup jelas digambarkan dalam teks Fragmen Carita Parahyangan (FCP) (abad ke-16 M). Hal ini tidak semata-mata ditentukan oleh seorang prebu, akan tetapi dilakukan atas kesepakatan dengan pihak rama dan pihak resi. Prebu-rama-resi inilah yang disebut sebagai Tri Tangtu di Buana (Tiga golongan yang menentukan roda kekuasaan di dunia). Sistem kekuasaan pada masyarakat Sunda pada masa itu harus dibagi-bagi sedemikian rupa sehingga yang satu terpisah dari yang lainnya. Hal tersebut tentunya sangat beralasan supaya kekuasaan kerajaan tidak terpusatkan pada satu tangan (raja). Dengan pemisahan kekuasaankekuasaan itu dapatlah dicegah tindakantindakan penguasa secara sewenang-wenang dan kebebasan berpolitik dalam kerajaan akan lebih terjamin.

Diuraikan dalam FCP lembar 5b bahwa, sang prebu itu harus ngagurat batu (menggores batu) yang berarti berwatak teguh dalam menjalankan aturan, sedangkan sang rama harus ngagurat lemah (menggores tanah) yang berarti berwatak bisa menentukan pijakan atau aturan bagi para pelaksana pemerintahan, dan sang resi harus ngagurat cai (menggores air) yang berarti berwatak menyejukkan dan adil. Di sini tampak adanya perbedaan antara organ dan fungsi itu (Darsa, dkk. 2000: 61).

Jika dibandingkan antara Trias Politica model Montesquieu dengan Tri Tangtu di Buana, model pembagian/pemisahan kekuasaan pada sistem Kerajaan Sunda masa lalu, maka peneliti dapat menganalogikannya sebagai berikut. Fungsi atau tugas kekuasaan di kerajaan Sunda ada tiga. Tiap-tiap fungsi atau tugas itu terpisahpisah sehingga organ atau badan yang satu tidak mencampuri fungsi atau tugas badan-badan lainnya. Hal yang dimaksud disiratkan secara jelas berikut ini:

1) Tugas legislatif dipegang oleh golongan Rama dan semata-mata boleh dijalankan oleh badan itu.

2) Tugas eksekutif menjadi wewenang Prebu yang semata-mata boleh dijalankan oleh badan itu.

3) Tugas yudikatif semata-mata dipegang oleh golongan Resi sebagai badan peradilan.

Jadi, jelaslah bahwa pemimpin pusat tidak serta merta diwariskan secara genealogis kepada putra sulung raja terdahulu. Akan tetapi, hal itu dilakukan atas kesepakatan dengan pihak rama (para tokoh wakil masyarakat) dan pihak resi (kaum intelektual ahli di bidang pengetahuan peradilan). Di lain pihak, pemimpin wilayah atau daerah itu juga ditentukan atas mekanisme kesepakatan dan kebijakan lembaga adat Tri Tangtu di Buana yang ada di masing-masing kerajaan daerah. Ini dapat memeperkecil terjadinya potensi gesekan atau konflik kepentingan di kalangan rakyat secara horizontal.

Dalam Tri Tangtu di Buana inilah banyak terjadi kegiatan politik yang di dalamnya mengandung aspek-aspek komunikasi politik yang terwujud dalam aktivitas komunikasi politik antar pemegang kekuasaan. Aktivitas komunikasi politik yang terjadi utamanya terjadi dalam proses pembagian/pemisahan kekuasaan dan pembagian wilayah kekuasaan dalam Kerajaan Sunda. Tri Tangtu di Buana kini masih tampak jelas dalam tradisi kehidupan masyarakat Baduy di Kanekes yang terpusatkan pada "Tangtu Telu" atau tiga kapuunan, yakni Cibeo berkedudukan sebagai Puun Ponggawa (dapat diidentikkan sebagai Prebu), Cikartawana berkedudukan sebagai Puun Resi, dan Cikeusik berkedudukan sebagai Puun Rama.

Salah satu naskah Sunda kuno yang isinya mengandung aspek-aspek komunikasi politik Tri Tangtu di Buana dan masyarakat Sunda kuno pada umumnya adalah Fragmen Carita Parahyangan (FCP). Teks naskah $F C P$ berwujud sebuah tulisan tangan yang hingga saat ini hanya ditemukan dalam satu buah naskah, itu pun tersimpan bersatu dengan naskah Carita Parahyangan (CP) dalam sebuah Kropak 406 yang kini tersimpan di bagian koleksi naskah Perpustakaan Nasional Jakarta. Naskah FCP mungkin dapat dikatakan memiliki keistimewaan tersendiri dalam khazanah pernaskahan Sunda Kuno karena 
selain berbahasa Sunda Kuno dan berbentuk prosa juga merupakan codex unicus (naskah tunggal). Secara garis besar, teks naskah FCP berisi mengenai tiga kisah utama para penguasa kerajaan Sunda yang berpusat di ibukota Pakuan Pajajaran. Ketiga kisah yang dimaksud adalah (1) pendahulu Maharaja Trarusbawa, (2) Maharaja Trarusbawa penguasa Pakuan Pajajaran yang bertakhta di keraton "Sri-Bima Punta Narayana Madura Suradipati”, dan (3) Rakeyan Darmasiksa penguasa dari Saunggalah yang mewarisi keraton di Pakuan Pajajaran (Darsa, dkk., 2000: 59-60).

Ada beberapa hal yang dapat digali dari isi teks FCP, di antaranya. Pertama, sistem pembagian kekuasaan didasarkan atas Tri Tangtu di Buana (tiga penentu urusan di negara) yang terdiri atas golongan: (1) Prebu ialah raja yang bisa dianalogikan sebagai pemegang lembaga eksekutif, (2) Rama ialah tokoh yang dituakan oleh masyarakat yang bisa dianalogikan sebagai pemegang lembaga legislatif, dan (3) Resi ialah kaum "akademisi" dan agamawan yang bisa dianalogikan sebaga pemegang lembaga yudikatif. Kedua, sistem birokrasi dalam hal kekuasaan mengatur seluruh daerah di dalam wilayah kerajaan telah tampak didasarkan atas sistem desentralisasi yang terbagi menjadi 12 wilayah penguasa yang memungkinkan daerah-daerah itu tumbuh secara otonom (Sunda: berkembang sesuai dengan ciri sabumi cara sadésa). Inilah salah satu ciri telah tumbuhnya "Bhineka Tunggal Ika". Ketiga, model pengaturan pemerintahan yang dikelola melalui pangwereg yang bersifat top-down dan pamwatan yang bersifat bottomup dalam upaya meningkatkan stabilitas otonomi daerah demi menjamin kehidupan kesejahteraan masyarakat.

Dengan demikian, isi teks naskah $F C P$ ini telah mampu memberikan sebagian gambaran bahwa masyarakat Sunda di masa lampau telah memiliki satu taraf kehidupan sosial kemasyarkatan yang cukup teratur, seperti juga sebagian masyarakat lainnya yang ada di Nusantara. Masyarakat lama telah mewariskan sesuatu yang mungkin sama sekali di luar perhitungan dan perkiraan kita saat ini. Masalahnya, antara lain, kurangnya pengetahuan dan pengenalan kita terhadap khazanah pernaskahan bangsa kita sendiri.
Terbukti, banyak hal yang saat ini sedang menjadi urusan besar, namun telah terbiasa bagi masyarakat masa silam.

Setelah penulis membaca dengan seksama terjemahan teks dalam naskah $F C P$ ini, penulis tertarik untuk melakukan sebuah penelitian kualitatif untuk mengetahui makna Tri Tangtu di Buana yang mengandung aspek komunikasi politik dalam Fragmen Carita Parahyangan. Penulis memilih untuk meneliti makna Tri Tangtu di Buana yang mengandung aspekaspek komunikasi politik setelah sebelumnya melakukan pra-penelitian untuk mengetahui konteks komunikasi apa saja yang terkandung dalam FCP ini. Ternyata, setelah penulis melakukan pra-penelitian tersebut, konteks komunikasi politiklah yang mendominasi teks $F C P$, karena sejatinya $F C P$ berisi teks-teks yang berkaitan dengan sistem pemerintahan yang sarat dengan unsur politik dan aktivitas komunikasi politik yang melibatkan orangorang dalam tiga kelembagaan Tri Tangtu di Buana. Penulis memilih beberapa bagian teks $F C P$ berdasarkan nomor lembar halaman yang mengandung aspek-aspek komunikasi politik dalam Tri Tangtu di Buana (apakah itu teks yang mengandung unsur aktor politik, pembicaraan politik, dan sebagainya).

Naskah FCP yang mengandung Tri Tangtu di Buana ini digarap dan ditransliterasi oleh Dr. Undang Ahmad Darsa, M.Hum., salah seorang filolog dari Universitas Padjadjaran. Penelitian ini bertujuan untuk mendeskripsikan naskah $F C P$ beserta teksnya sejelas mungkin. Penggarapan naskah FCP ini didasarkan atas kajian secara filologi dengan menerapkan metode edisi tunggal. Sedangkan untuk memahami isinya dilakukan tinjauan berdasarkan konsep-konsep kajian historiografi tradisional. Penelitian Undang ini menghasilkan teks-teks naskah FCP yang telah ditransliterasi ke dalam Bahasa Indonesia. Hasil dari transliterasi itulah yang digunakan oleh penulis untuk menghimpun berbagai data yang digunakan. Bila penelitian ini merupakan kajian filologi murni, maka penelitian yang dilakukan oleh penulis di dalam artikel ilmiah ini banyak menonjolkan hal-hal yang berkaitan dengan ilmu komunikasi, khususnya dalam konteks komunikasi politik dalam lingkup Tri Tangtu di Buana. Berdasarkan paparan di atas, 
maka tujuan dari penelitian ini adalah untuk mengungkap makna Tri Tangtu di Buana yang mengandung aspek komunikasi politik dalam Fragmen Carita Parahyangan.

\section{METODE PENELITIAN}

Penelitian ini masuk ke dalam paradigma interpretatif, sedangkan tradisi yang mendukung penelitian ini adalah tradisi fenomenologis, adapun tradisi fenomenologis ini masuk ke dalam paradigma interpretatif. Tradisi fenomenologis sendiri menekankan pada proses interpretasi, sehingga pada metode penelitian akan digunakan metode analisis hermeneutik sebagai "alat" untuk menginterpretasikan makna teks yang akan diteliti. Penelitian ini bertujuan untuk mengungkap makna Tri Tangtu di Buana yang mengandung aspek komunikasi politik dalam naskah Sunda Kuno Fragmen Carita Parahyangan. Oleh karena itulah, kerangka pemikiran penulis dalam penelitian ini adalah paradigma interpretatif, di mana proses interpretasi naskah dengan tradisi pendukung penelitian kualitatif analisis hermeneutik digunakan sebagai "alat" untuk menyingkap makna Tri Tangtu di Buana yang terkandung dalam naskah Sunda kuno FCP ini.

Sumber data penelitian ini adalah teks hasil transliterasi naskah Sunda kuno berjudul Fragmen Carita Parahyangan (FCP). Dalam penelitian ini, pertama-tama penulis mengamati seluruh teks $F C P$. Tetapi, tidak semua teks yang terkandung dalam FCP ini akan dianalisis. Penulis hanya menganalisis teks-teks yang mengandung unsur-unsur Tri Tangtu di Buana, yang di dalamnya mengandung aspek-aspek komunikasi politik. Aktor politik, pesan-pesan politik, pembicaraan politik, atau hubunganhubungan antar elit politik dalam lingkup Tri Tangtu di Buana telah tertuang dalam FCP ini.

Setelah penulis membaca dan memahami seluruh isi teks $F C P$, penulis memilih beberapa bagian teks berdasarkan nomor lembar halaman yang mengandung unsur Tri Tangtu di Buana (di dalamnya terkandung unsur aktor politik, pembicaraan politik, dan sebagainya). Dalam tahap pemilihan teks ini, penulis berupaya memperhatikan unsur-unsur kata dan kalimat yang dipakai dalam teks $F C P$.

Bagian teks yang dipilih oleh penulis adalah bagian teks $F C P$ lembar $7 \mathrm{~b}-8$ a dan lembar $25 \mathrm{a}-$ 3b. Penulis memilih bagian teks ini karena di dalamnya merepresentasikan Tri Tangtu di Buana, khususnya dalam lingkup Kerajaan Sunda. Secara tidak langsung, bagian teks ini juga menjelaskan keseluruhan isi teks FCP yang bernuansa historis-politis. Jadi, dengan membaca bagian teks ini, penulis berpendapat bahwa sebagian besar kandungan makna dalam teks FCP ini sudah dapat diketahui. Hal ini sejalan dengan prinsip hermeneutika, yakni satu bagian untuk seluruhnya, dan seluruhnya untuk satu bagian.

Setidaknya ada dua jenis metode pengumpulan data yang dilakukan oleh penulis, yaitu menggunakan analisis teks dan wawancara. Analisis teks yang dilakukan penulis adalah menafsirkan makna Tri Tangtu di Buana yang terkandung dalam teks naskah Sunda kuno FCP yang telah terlebih dulu ditransliterasi ke dalam huruf latin dan diterjemahkan ke dalam bahasa Indonesia (berhubung teks FCP ditulis dalam aksara dan bahasa Sunda Kuno) melalui lima tahap analisis hermeneutik Paul Ricoeur. Dari naskah tersebut, penulis kemudian menafsirkan makna-makna yang terkandung di dalam Tri Tangtu di Buana; yang di dalamnya mengandung aspek-aspek komunikasi politik, apakah itu menyangkut aktor politik atau pesanpesan politiknya. Naskah tersebut merupakan sumber informasi (media) dan sumber data dalam menggarap penelitian ini. Sedangkan metode wawancara yang dipakai oleh penulis adalah metode wawancara secara mendalam. Untuk menggali informasi-informasi yang dibutuhkan dari naskah $F C P$, penulis telah mewawancarai salah seorang filolog yang memang ahli di bidang pernaskahan Sunda kuno. Filolog yang penulis wawancarai adalah Dr. Undang Ahmad Darsa, M.Hum. Beliau adalah dosen sekaligus peneliti yang ahli dalam bidang penggarapan naskah-naskah Sunda kuno, sekaligus penggarap naskah Fragmen Carita Parahyangan (FCP). Wawancara dilakukan dengan teknik wawancara mendalam, di mana informasi tambahan akan penulis dapatkan dari beliau. Tentu saja data yang peneliti dapatkan dari hasil wawancara ini sangat berguna untuk menunjang penelitian yang tengah dilakukan.

Penulis menggunakan metode penelitian kualitatif untuk melakukan penelitian ini. 
Mengingat sumber berdasarkan kaitan dengan teks lain, dan makna teks berdasarkan dialog teks dengan pembaca. Telah dijelaskan di atas bahwa penelitian ini dianalis dengan analisis hermeneutik. Secara etimologis, hermeneutika berasal dari kata hermeneuin, bahasa Yunani, yang berarti menafsirkan atau menginterpretaskan. Secara mitologis, hermeneutika dihubungkan dengan Hermes, nama Dewa Yunani yang menyampaikan pesan Illahi kepada manusia. Pada dasarnya medium pesan dan bahasa, baik bahasa lisan maupun bahasa tulisan. Jadi, penafsiran disampaikan lewat bahasa, bukan bahasa itu sendiri. Karya sastra perlu ditafsirkan sebab di satu pihak karya sastra terdiri atas bahasa, sedangkan di pihak lain, di dalam bahasa sangat banyak makna yang tersembunyi, atau dengan sengaja disembunyikan (Ratna, 2009: 45).

Hymes (dalam Kuswarno, 2009: 25), dengan spesifik menyebutkan bahwa secara tradisional, hermeneutika merupakan ilmu atau seni yang diaplikasikan untuk memahami tulisan. Karena variasi sumber tertulis akan menghasilkan informasi mengenai pola-pola penggunaan bahasa dan kebudayaan dari masyarakat yang menghasilkan tulisan tersebut.

Dasar teori hermeneutika adalah asumsi bahwa manusia secara aktif senantiasa menginterpretasikan pengalamannya dengan cara memberi makna terhadap apa pun yang dilihatnya. Atas dasar itulah maka interpretasi merupakan proses kegiatan kreatif agar bisa mengungkapkan makna teks suatu naskah dari berbagai kemungkinan makna. Dengan kata lain, hermeneutika adalah kajian untuk mengerti melalui interpretasi, khususnya tindakan dan teks. Jadi, teori tentang proses mengerti ini disebut hermeneutika. Adapun pengertian teks mencakup segala bentuk rekaman dan berbagai aspek tindakan manusia, baik sebagai perseorangan maupun sebagai kelompok budaya.

Hermeneutika ditujukan untuk mengerti perasaan orang, makna suatu peristiwa, atau menerjemahkan suatu tindakan sehingga dapat dimengerti oleh orang lain. Atas dasar ini, hermeneutika dapat dibedakan ke dalam dua kelompok, yaitu hermeneutika tekstual yang diterapkan untuk mengerti teks, dan hermeneutika kultural yang diterapkan untuk mengungkapkan makna tindakan. Teks itu sendiri terbagi atas teks lisan berupa folklore dan teks tertulis yang di antaranya dalam wujud naskah. Namun pada dasarnya, baik teks lisan maupun teks tertulis itu bersifat abstrak dan kekal. Di samping itu, teks dapat dikategorikan sebagai teks illahiah berupa wahyu yang bersifat dogmatis dan teks insaniah berupa karya-karya kreasi manusia yang bersifat profan (populer). Dalam hal folklor yang datanya diperoleh secara lisan, data itu harus diafiksasikan terlebih dahulu ke dalam bentuk teks. Ricoeur (1976: 29) berpendapat bahwa teks adalah wacana (berarti lisan) yang diafiksasikan ke dalam bentuk tulisan. Sebuah teks mempunyai tiga tingkat otonomisasi, yaitu otonomisasi yang berhubungan dengan penulis, otonomisasi yang berhubungan dengan kondisi-kondisi sosialbudaya, dan otonomisasi yang berhubungan dengan pembaca.

Karena objek utama hermenutika adalah teks, dan teks adalah hasil atau produk praksis berbahasa, maka antara hermeneutika dengan bahasa akan terjalin hubungan sangat dekat, sehingga kajian hermeneutika tidak lain adalah juga kajian terhadap bahasa secara filosofis (Raharjo, 2008: 33). Penafsiran teks sastra setidaknya akan mengkuti salah satu atau lebih dari enam pokok rambu-rambu (Endraswara, 2008: 43-45), yaitu:

Penafsiran yang bertitik tolak dari pendapat, bahwa teks sendiri sudah jelas. Menurut pandangan ini, maka isyarat-isyarat dan susunan teks membuka kesempatan bagi seorang pembaca yang kompeten untuk menemukan arti yang tepat; Penafsiran yang berusaha menyusun kembali arti historik. Dalam pendekatan ini si juru tafsir dapat berpedoman pada maksud si pengarang seperti nampak pada teks sendiri atau di luar teks; Penafsiran hermeneutik baru yang terutama diwakili oleh Gadamer berusaha memadukan masa silam dengan masa kini. Juru tafsir sadar, bahwa ia berdiri di tengah-tengah suatu arus sejarah yang menyangkut baik penerimaan maupun penafsiran: cara ia mengerti sebuah teks turut dihasilkan sebuah tradisi; Penafsiran yang bertolak pada pandangannya sendiri mengenai sastra. Ini seringkali dilakukan dengan pretensi bahwa kita dapat menunjukkan arti teks yang pokok; Penafsiran yang berpangkal pada suatu problematik 
tertentu, misalkan dari aspek politik, psikologis, sosiologis, moral dan sebagainya. Dari model hermeneutik ini, berarti penafsiran karya sastra bersifat parsial, hanya bagian tertentu saja yang sejalan dengan isu strategis; Tafsiran yang tak langsung berusaha agar memadahi sebuah teks diartikan, melainkan hanya ingin menunjukkan kemungkinan-kemungkinan yang tercantum dalam teks, sehingga pembaca sendiri dapat menafsirkannya. Pendekatan yang berkiblat pada pembaca ini dinamakan estetik-reseptif.

Dalam penelitian ini, penulis memilih untuk menggunakan analis hermeneutik Paul Ricoeur. Ricoeur (dalam Sumaryono, 1999: 107) mendefinisikan hermeneutika sebagai teori pengoperasian pemahaman dalam hubungannya dengan interpretasi terhadap teks. Tugas hermeneutika menurut Ricoeur adalah mencari dinamika internal yang mengatur struktural kerja di dalam sebuah teks dan mencari daya yang dimiliki kerja teks untuk memproyeksikan diri ke luar dan memungkinkan isi teks tersebut muncul ke permukaan.

Sebuah kata yang diucapkan secara verbal maupun yang tertulis sebenarnya memiliki makna lebih dari satu bila dihubungkan dengan konteks yang berbeda. Pemaknaan ini dikarakteristikan sebagai polisemi oleh Ricoeur. Sebuah teks selalu berhubungan dengan masyarakat, tradisi, ataupun budaya yang ada. Sebuah teks adalah diskursus, bila dituangkan dalam tulisan. Sebagai diskursus, dialektika peristiwa-arti dan dialektika artireferensi berlaku pula pada teks. Oleh Ricoeur, hubungan antara peristiwa dan arti dinyatakan dalam suatu aksioma:

"Jika semua diskursus diaktualisasi sebagai suatu peristiwa, semua diskursus dipahami sebagai arti. Sebagai peristiwa, diskursus bersifat berlalu, tetapi sebagai arti, diskurusus bertahan di dalam isi proporsional. Dengan ini, pengalaman individual menjadi umum lewat diskursus. Arti menjadi umum, tetapi pengalaman sebagai sesuatu yang terhayati tetap bersifat individual, pribadi. Arti merupakan sisi objektif diskurusus, sedangkan peristiwa merupakan sisi subjektifnya," (Ricoeur, dalam Poespoprodjo, 2004: 122).

Karena berupa tulisan, teks mencapai otonomi semantik dalam kaitannya dengan pembicara, pendengar aslinya, dan situasi diskursif yang umum pada yang ikut berbicara. Dengan dituangkan dalam tulisan, sebuah teks menjadi otonom; dengan kata lain teks terlepas dari maksud penciptanya. Makna teks pun tidak lagi tumpang tindih dengan maksud penciptanya.

Penafsiran sebuah teks tak akan terlepas dari bahasa yang tidak pernah tanpa pengandaian dan situasi penafsir pada waktu tertentu. Kesenjangan ini membuat Ricoeur menyatakan bahwa sebenarnya teks itu mempunyai tempat di antara penjelasan struktural dan pemahaman hermeneutik. Seperti dalam aksioma yang disebutkannya, penjelasan struktural (dalam hal ini arti teks) bersifat objektif dan pemahaman hermeneutik (dalam hal ini peristiwa) yang memberi kesan subjektif. Dikotomi ini menimbulkan sebuah permasalahan baru. Teks memiliki sifat otonom untuk melakukan dekontekstualisasi (proses pembebasan dari konteks) baik dari sudut pandang sosiologis maupun psikologis serta melakukan rekonekstualisasi (proses masuk kembali ke dalam konteks) secara berbeda dalam tindakan membaca.

Menurut Ricoeur, otonomi teks ada tiga macam, yaitu intensi atau maksud pengarang, situasi kultural dan kondisi sosial pengadaan teks, dan untuk siapa teks itu dimaksudkan (dalam Sumaryono, 1999: 109). Atas dasar otonomi ini, maka yang dimaksud dengan dekontekstualisasi adalah materi teks melepaskan diri dari tujuan yang terbatas pada pengarang. Teks membuka diri seluas-luasnya untuk dimana pembacaan selalu berbeda-beda (rekontekstualisasi). Dalam memahami teks, Ricoeur mengatakan bahwa ada tiga langkah pemahaman, yaitu yang pertama langkah simbolik (pemahaman dari simbol ke simbol), yang kedua pemberian makna terhadap simbol dan pemberian yang cermat atas makna, serta yang ketiga adalah langkah filosofis, berpikir dengan menggunakan simbol sebagai titik tolak (dalam Sumaryono, 1999: 111). Simbol-simbol ini bisa bermakna ganda, sehingga simbol selalu dapat ditafsirkan dan diurai kembali. Simbol merangsang manusia untuk mengadakan refleksi sehingga mengawali setiap pemikiran religius, filsafat, dan ilmu. Simbol senantiasa harus dapat diberi arti dan interpretasi baru (Poespoprodjo, 2004: 128). 
Ricoeur (1976: 30) mengembangkan teori melingkar ini ke dalam dialog antara explanation dan understanding. Explanation merupakan kajian yang bersifat analitis dan empiris sehingga kajian dilakukan terhadap obyek yang terdiri atas unsur-unsur yang telah terpolakan walaupun unsur-unsur yang telah terstruktur ini belum mengungkapkan makna apa pun. Makna itu baru akan terungkapkan setelah unsur-unsur ini diproyeksikan menjadi sebuah pola yang utuh untuk kemudian diletakkan pada tahap interpretasi. Jadi, interpretasi adalah tahap sintesa, dan interpretasi dilakukan terhadap pola yang menyeluruh dan utuh tadi. Dengan demikian, lingkaran hermeneutik terjadi antara explanation ke understanding dan kembali ke explanation dan seterusnya. Berikut ini adalah tahapan-tahapan yang dilakukan penulis dalam menganalisis teks secara hermeneutik dengan menggunakan metode analisis hermeneutik Paul Ricoeur:

Tahap pertama, makna teks berdasarkan unsur-unsur pembentukan teks (bahasa). Pada tahap ini, penulis menafsirkan bagian teks dengan cara membagi lagi bagian-bagian teks tersebut ke dalam beberapa kalimat. Setelah penulis mambagi lagi bagian teks tersebut, penulis menafsirkannya berdasarkan bahasa yang dipakai oleh pembuat teks. Dengan kata lain, makna teks akan coba diungkap dari konstruksi kalimat yang tersurat dalam naskah.

Tahap kedua, makna teks berdasarkan latar belakang produksi teks. Pada tahap ini, penulis menafsirkan teks berdasarkan makna yang berusaha disampaikan oleh pembuat teks berdasarkan latar belakang kehidupan dan pikiran sang pembuat teks. Pembuat teks sendiri adalah sekelompok kaum intelektual Kerajaan Sunda pada waktu Maharaja Trarusbawa memegang tampuk pimpinan. Sang pembuat teks sendiri menempatkan diri pada masanya sebagai wakil dari komunitas masyarakat pemilik naskah. Jadi, makna teks akan diungkap dari sisi sang pembuat teks secara historis.

Tahap ketiga, makna teks berdasarkan lingkungan teks. Pada tahap ini, penulis menafsirkan teks berdasarkan situasi sosialkemasyarakatan masyarakat Sunda pada abad ke-16 dan kepada siapa saja teks $F C P$ ini dikomunikasikan.

Tahap keempat, makna teks berdasarkan kaitan dengan teks lain merupakan salah satu bentuk dari intertekstualitas yang memang menjadi ciri utama dari hermeneutik. Jadi, penulis menganalisis data yang berasal dari teks FCP tentang makna Tri Tangtu di Buana dan dikaitkan juga dengan teks-teks lain yang juga berhubungan, baik itu teks-teks yang berasal dari bagian lain naskah $F C P$ ataupun teks-teks yang berasal dari naskah Sunda kuno lainnya (yang terkait dengan Tri Tangtu di Buana juga tentunya). Teks-teks lain yang berkaitan dengan Tri Tangtu di Buana dalam FCP antara lain teks yang terkandung dalam naskah Amanat Galunggung tentang pembagian kekuasaan, teks dalam naskah Sang Hyang Hayu yang berkaitan dengan konsep "Tiga Rahasia", dan konsep Tri Buana yang merupakan sebuah sistem kosmologis masyarakat Sunda. Pada tahap ini akan diketahui hubungan antara teks Tri Tangtu di Buana dalam FCP dengan teksteks lainnya.

Tahap terakhir, makna teks berdasarkan dialog teks dengan pembaca. Teks yang membahas tentang Tri Tangtu di Buana yang diciptakan oleh pengarang dalam naskah $F C P$, yang diciptakan oleh sang pengarang pada abad ke-16 Masehi, berdialog dengan peneliti yang memiliki dasar pemikiran abad ke-21 Masehi. Karena perbedaan zaman inilah, memungkinkan terjadinya perbedaan pemikiran. Oleh karena itu, dibutuhkan dialog antara pikiran pengarang $F C P$ yang diwakili oleh teks $F C P$ dengan pikiran penulis. Jadi, pikiran penulis saat ini direfleksikan dengan teks-teks yang terkandung dalam naskah FCP. Teks-teks yang tentunya mengadung makna $T r i$ Tangtu di Buana. Setelah proses selesai, pada tahap ini akan diketahui makna Tri Tangtu di Buana dalam pikiran penulis.

\section{HASIL DAN PEMBAHASAN}

Penelitian ini bertujuan untuk mengetahui makna Tri Tangtu di Buana sebagai tiga kelembagaan Kerajaan Sunda yang mengandung aspek-aspek komunikasi politik dalam naskah Sunda Kuno Fragmen Carita Parahyangan $(F C P)$. Data-data yang dianalisis dan dibahas pada bab ini berasal dari teks naskah $F C P$ dengan menggunakan analisis hermeneutik. Dalam naskah $F C P$, penulis 
mendapatkan gambaran mengenai berbagai aspek komunikasi politik yang melibatkan tiga kelembagaan dalam Tri Tangtu di Buana, yaitu prebu, rama, dan resi. Sebagaimana unsur-unsur komunikasi pada umumnya, maka komunikasi politik pun terdiri dari beberapa unsur. Salah satu model komunikasi yang cukup simpel dan mewakili aspek-aspek dalam komunikasi adalah model yang dikemukakan oleh Harold Lasswell (1948) yang menggambarkan proses komunikasi dan fungsi-fungsi yang diembannya dalam masyarakat (Mulyana, 2007: 147). Model komunikasi Lasswell berupa ungkapan verbal, yakni who says what in which channel to whom with what effect? Bila dijabarkan berdasarkan model tersebut, maka unsur-unsur komunikasi politik meliputi komunikator politik, pesan politik, media komunikasi politik, komunikan politik dan efek apa yang terjadi setelah komunikan menerima pesan politik dari komunikator politik.

FCP dapat dikatakan sebagai salah satu media penyampai pesan mengenai sekelumit kehidupan masyarakat Sunda Kuno pada masa Kerajaan Sunda masih berdiri. FCP berisi teks-teks yang menyangkut aspek komunikasi politik suprastruktur Kerajaan Sunda, yang di dalamnya terdapat banyak sekali pesan-pesan komunikasi politik yang dipertukarkan oleh para elit politik Kerajaan Sunda. Untuk menyingkap makna Tri Tangtu di Buana dari pesan-pesan yang terkandung dalam $F C P$ tersebut, penulis menggunakan metode analisis hermeneutik. Salah satu tokoh yang merupakan ahli dari teori penafsiran hermeneutika adalah Paul Ricoeur. Penafsiran naskah sangat penting ketika pembicara dan penulis tidak tersedia, seperti pada teks-teks yang terkandung dalam naskahnaskah Sunda kuno. Namun, hal tersebut tidak perlu dibatasi pada situasi ini saja. Sebenarnya, naskah itu sendiri selalu berbicara kepada kita dan pekerjaan juru bahasa adalah untuk menemukan arti dari apa yang dikatakan oleh naskah tersebut. Bagi Ricoeur, pembaca selalu menguji penafsiran mereka dengan melihat pada fitur-fitur naskah untuk menemukan makna yang ada di dalamnya (Littlejohn, 2009: 197).

Seperti yang telah dijelaskan pada bab-bab sebelumnya, Kerajaan Sunda menganut sistem pemisahan/pembagian kekuasaan Tri Tangtu di Buana, di mana sistem pemerintahan kerajaan dijalankan oleh tiga unsur (prebu, rama, resi). Pada sekitar abad ke-17 Masehi, Montesquieu di dalam bukunya Esprit des Lois mengemukakan sebuah konsep pemisahan kekuasaan yang kita kenal bernama Trias Politica yang mengandung tiga fungsi kekuasaan, yaitu kekuasaan legislatif (la puissance legislatief), kekuasaan eksekutif (la puissance executief) dan kekuasaan yudikatif (la puissance de juger) (Harun \& Sumarno, 2006: 43-44).

Kerajaan Sunda sendiri adalah sebuah federasi yang menganut sistem desentralisasi, di mana wilayahnya terbagi atas 12 negara bagian, yakni Galunggung, Denuh, Sanghyang Talagawarna, Mandala Cidatar, Geger Gadung, Windupepet, Galuh Wetan, Mandala Utama Jangkar, Mandala Pucung, Reuma, Lewa, dan Kandangwesi. Masing-masing negara bagian/ wilayah memiliki Tri Tangtu di Buana (prebu, rama, resi) tersendiri (di Indonesia sekarang sejenis dengan gubernur dan DPD).

Dalam wilayah sistem, komunikasi politik akan selalu berada dalam dua suasana, yaitu dalam suasana pemerintahan (the governmental communication sphare) yang disebut pula suprastruktur komunikasi, dan suasana kehidupan dalam masyarakat (the socio communication sphare) yang disebut juga infrastruktur komunikasi (Harun \& Sumarno, 2006:42). TeksFCPmemuatsuasanakomunikasi yang pertama, yakni dalam tataran suprastruktur komunikasi, yang di dalamnya tentu melibatkan pertukaran pesan-pesan komunikasi politik antarelit politik yang memegang jabatan tinggi di Kerajaan Sunda. Oleh karena itu, penulis tertarik untuk menganalisis dan membahas makna Tri Tangtu di Buana yang sarat dengan aspek komunikasi politik yang terkandung dalam teks $F C P$ ini, karena isi dari naskah $F C P$ ini sendiri bernuansa politik, sehingga menurut pandangan penulis, penelitian tentang komunikasi politik yang melibatkan orangorang dalam tatanan suprastruktur komunikasi Kerajaan Sunda sangat menarik untuk diteliti; selain karena penelitian ini diharapkan mampu membuka khazanah penelitian tentang aspekaspek komunikasi politik di masa lampau.

Pada tahap pertama, penulis membahas dan menganalisis bagian-bagian teks (mengungkap makna Tri Tangtu di Buana berdasarkan konstruksi kalimatnya). Dalam 
FCP yang di dalamnya melibatkan Tri Tangtu di Buana yang mengandung aspek-aspek komunikasi politik di Kerajaan Sunda. Hal ini ditandai oleh terdapatnya pesan-pesan yang isinya menyangkut pembagian/ pemisahan kewenangan dan kewajiban Tri Tangtu di Buana (prebu, rama, resi). Para pemangku kebijakan dalam masyarakat ini mendapatkan mandat dari aturan atau ketentuan tentang apa yang boleh dan tidak boleh dilakukan oleh para penyelenggara pemerintahan pada masa itu. Pesan-pesan tentang pembagian kekuasaan ini tersurat dalam FCP lembar 7b-8a.

Bagian ini mewakili tahap pertama dalam analisis hermeneutik Ricoeur, yakni mengungkap makna unsur-unsur pembentukan teks (bahasa). Tahap ini meliputi analisis yang dilakukan dengan cara membagi lagi bagian teks yang dianalisis menjadi beberapa kalimat. Beberapa kalimat dari bagian teks ini dianalisis berdasarkan makna bahasanya. Hal ini bisa dilihat dari analisis dan pembahasan dari kutipan bagian-bagian teks di bawah ini, yaitu bagian-bagian teks naskah $F C P$ yang berisi pembagian kekuasaan yang mengandung aspek komunikasi politik dalam Tri Tangtu di Buana tersebut:

Maharaja Trarusbawa berkata, "Bagi kalangan Resi diperkenankan melaksanakan seperangkat aturan dasar demi kedamaian di seluruh negeri, yang bertanggung jawab atas urusan kesentosaan. Kalangan Rama (diperkenankan) merumuskan seperangkat aturan dasar demi ketertiban undang-undang pemerintahan, yang bertanggung jawab atas urusan bimbingan. Kalangan Prebu diperkenankan melaksanakan rumusan seperangkat aturan dasar demi ketertiban kedudukan pemimpin (raja), yang bertanggung jawab atas urusan pemerintahan..." (lembar nomor 7b)

Kalimat-kalimat yang terdapat dalam kutipan teks di atas merupakan kalimat berita tidak langsung yang berisikan titah Maharaja Trarusbawa, di mana pembagian kewenangan dan tugas kenegaraan bagi kalangan prebu, rama dan resi masih menjadi isi dari teks yang terkandung pada bagian ini. Prebu merupakan kepala pemerintahan, rama adalah wakil dari kerajaan yang bertugas membimbing rakyat, sedangkan resi merupakan pengadil. Setelah
Maharaja Trarusbawa melakukan pembagian kewenangan dan tugas tersebut, beliau pun menyampaikan sebuah kalimat yang di dalamnya terdapat nilai moral, seperti yang tertuang dalam kutipan teks berikut:

“...Oleh karena itulah tidak pantas bila berebut kedudukan, dan hendaknya janganlah khawatir saling berebut wilayah kekuasaan. Nah, begitulah kalian bagi kalangan Prebu, Rama, dan Resi semua sebagai kaum pejabat pengatur tanah air..." (lembar nomor 7b)

Kedua kalimat ini adalah kalimat penyimpulan dari kalimat sebelumnya yang berisi pembagian kekuasaan prebu, rama dan resi oleh Maharaja Trarusbawa. Karena kalangan prebu, rama dan resi telah diberikan wewenang masing-masing, maka tidak ada alasan bagi masing-masing orang yang memegang jabatan untuk berebut kedudukan dan wilayah kekuasaan, karena seluruhnya sudah diatur dengan adil oleh Maharaja Trarusbawa. Akhirnya, beliau memperjelas kalimat pembagian kekuasaan tersebut dengan sebuah kalimat penegasan, seperti yang tercantum dalam kutipan berikut:

“...Jikalah sudah sepakat semua, maka mengenai urusan kekuatan itu bagian kalangan Prebu, urusan kata-kata itu bagian kalangan Rama, dan urusan pikiran dan perasaan itu bagian kalangan Resi." (lembar nomor 8a)

Kalimat ini adalah penutup dari bagian kedua. Maharaja Trarusbawa kembali memberikan penjelasan peran prebu, rama dan resi dalam menjalankan tugas kenegaraannya. Hanya saja, kalimat yang dipakai lebih tersirat. Prebu memegang urusan kekuatan, artinya prebu memiliki kekuasaan untuk menjalankan roda pemerintahan dan berperan pula sebagai penentu kebijakan, rama memegang urusan kata-kata, artinya rama adalah penyalur aspirasi dari rakyat pada pemimpin, dan pembimbing untuk rakyat. Resi memegang urusan pikiran dan perasaan, artinya resi berperan sebagai “otak dan hati" kerajaan; di mana resi berperan besar untuk masalah peradilan demi mewujudkan negara yang adil, makmur dan sentosa.

Kalimat-kalimat yang terdapat dalam kutipan teks pembagian kekuasaan merupakan 
kalimat berita tidak langsung yang berisikan titah Maharaja Trarusbawa, di mana pembagian kewenangan dan tugas kenegaraan bagi kalangan prebu, rama dan resi masih menjadi isi dari teks yang terkandung pada bagian ini. Prebu merupakan kepala pemerintahan, rama adalah wakil dari kerajaan yang bertugas membimbing rakyat, sedangkan resi merupakan pengadil. Karena kalangan prebu, rama dan resi telah diberi wewenang masing-masing, maka tidak ada alasan bagi masing-masing orang yang memegang jabatan untuk berebut kedudukan dan wilayah kekuasaan, karena seluruhnya sudah diatur dengan adil oleh Maharaja Trarusbawa. Prebu memegang urusan kekuatan, artinya prebu memiliki kekuasaan untuk menjalankan roda pemerintahan dan berperan pula sebagai penentu kebijakan, rama memegang urusan kata-kata, artinya rama adalah penyalur aspirasi dari rakyat pada pemimpin, dan pembimbing untuk rakyat. Resi memegang urusan pikiran dan perasaan, artinya resi berperan sebagai "otak dan hati” kerajaan; di mana resi berperan besar untuk masalah peradilan demi mewujudkan negara yang adil, makmur dan sentosa.

Selain pesan-pesan yang isinya menyangkut pembagian/pemisahan kewenangan dan kewajiban Tri Tangtu di Buana (prebu, rama, resi) oleh Maharaja Trarusbawa, dalam naskah $F C P$ juga terdapat aktivitas komunikasi politik dalam Tri Tangtu di Buana yang terkait dengan pembagian wilayah kekuasaan di Kerajaan Sunda. Pembagian wilayah kekuasaan ini tersurat dalam $F C P$ lembar 25a sampai awal lembar nomor $3 b$. Sistem pembagian wilayah kekuasaan ini berisi tentang pesan-pesan yang disampaikan oleh Maharaja Trarusbawa dan orang-orang berpengaruh di kalangan kerajaan yang membagi wilayah kekuasaan kepada para pemangku jabatan wilayah dalam masyarakat Sunda kuno. Bagian-bagian teks naskah FCP yang berisi pembagian wilayah kekuasaan Kerajaan Sunda yang mengandung aspek komunikasi politik dalam Tri Tangtu Di Buana tersurat dalam bagian-bagian teks berikut:

Dikatakan bahwa anak-anaknya yang bernama Sang Resi Putih, Bagawat Sangkan Windu, Bagawat Cinta Kelepa, Bagawat Cinta Putih, Bagawat Angga Sunyia, Bagawat Tiga
Mrewasa, Bagawat Angga Brama, Bagawat Resi Karangan, Bagawat Cinta Premana, Bagawat Tiga Warna, Bagawat Pitu Rasa kembali ke Pakuan, ke keraton Sri "Bima Punta Narayana Madura Suradipati”. Datang mengabdi kepada Maharaja Trarusbawa, baik dari kalangan resi, raja, dengan premana... (lembar nomor 25a-26b)

Kalimat-kalimat pada bagian di atas berisikan informasi bahwa orang-orang kepercayaan Maharaja Trarusbawa datang ke Keraton Sri Bima Punta Narayana Madura Suradipati yang merupakan Pakuan (pusat pemerintahan) Kerajaan Sunda. Mereka yang datang adalah Sang Resi Putih, Bagawat Sangkan Windu, Bagawat Cinta Kelepa, Bagawat Cinta Putih, Bagawat Angga Sunyia, Bagawat Tiga Mrewasa, Bagawat Angga Brama, Bagawat Resi Karangan, Bagawat Cinta Premana, Bagawat Tiga Warna, dan Bagawat Pitu Rasa. Mereka semua datang ke Pakuan dengan tujuan untuk mengabdi kepada Maharaja Trarusbawa dengan cara menerima titah dari beliau untuk menjalankan pemerintahan di negara-negara bagian Kerajaan Sunda yang telah ditentukan.

Setelah kalimat-kalimat informatif tersebut, Maharaja Trarusbawa menyampaikan kalimatkalimat pelantikan yang berisi pengangkatan Sang Resi Putih sebagai rama di Galunggung. Seperti yang tersurat dalam kutipan teks berikut:

...Maharaja Trarusbawa berkata, "Anakku, Sang Resi Putih, engkaulah yang bertanggung jawab dalam urusan kependidikan; dinobatkan sebagai Batara Dangiang Guru di Galunggung, dan dijadikan sebagai pelindung wilayah, guna menaungi masyarakat daerah yang kegerahan, sebagai lambang ketenteraman negeri. Jaminan kehidupanmu adalah bertanggung jawab pada bidang pendidikan. Tanggung jawabmu ialah mengenai urusan kesejahteraan. Hendaklah jangan beristeri dua atau tiga, satu suami-isteri lebih mulia. Engkau akan dijadikan panutan seluruh masyarakat, dijadikan sebagai peneguh negeri, sebagai pijakan di bumi, kepercayaan setiap orang yang hidup. Apabila engkau berniat beristeri dua atau tiga dapat berdampak buruk sehingga dikatakan keadaan akan jadi kacau..." (lembar nomor 26b-26a)

Dalam bagian ini, Maharaja Trarusbawa menyampaikan pesan berupa kalimat langsung 
kepada Sang Resi Putih. Sang Resi Putih sendiri dinobatkan sebagai Batara Dangiang Guru, yaitu rama yang bertanggung jawab dalam urusan pendidikan dan ketentraman penduduk wilayah Galunggung. Pada kalimat kedua, pada intinya, Sang Resi Putih hanya boleh memiliki satu istri dan diharamkan berpoligami, karena apabila poligami dilakukan, maka akan terjadi hal yang tidak diharapkan. Disebutkan pula bahwa Sang Resi Putih yang bergelar Batara Dangiang Guru adalah seorang rama yang bertanggung jawab atas urusan kesejahteraan dan menjadi panutan masyarakat.

Lalu, setelah Maharaja Trarusbawa melantik Sang Resi Putih sebagai rama di Galunggung, beliau melantik Bagawat Sangkan Windu sebagai prebu di Denuh. Berikut kutipan teksnya:

...Tersebutlah kesepakatan para penerus seisi istana yang bernaung ke Pakuan. Oleh Maharaja Trarusbawa, Bagawat Sangkan Windu dinobatkan sebagai pemerkokoh Denuh. Hidupnya sebagai peneguh negeri serta seluruh manusia. "Isterimu mesti seorang, dan hendaknya jangan mendua atau tiga karena dapat berdampak buruk sehingga dikatakan keadaan akan jadi kacau, itulah yang dikhawatirkan..." (lembar nomor 26a-10a)

Dalam bagian ini, Maharaja Trarusbawa memberikan kewenangan kepada Bagawat Sangkan Windu untuk menjadi prebu di Denuh. Beliau ditugaskan sebagai pemimpin masyarakat. Sama seperti sebelumnya, Bagawat Sangkan Windu diharamkan untuk berpoligami karena dikhawatirkan keadaan akan menjadi buruk.

Selanjutnya, Maharaja Trarusbawa melantik Bagawat Resi Kelepa sebagai rama di Mandala Cidatar. Seperti yang tertuang dalam kutipan teks berikut:

...Tersebutlah kesepakatan para penerus seisi istana yang bernaung ke Pakuan. Bagawat Resi Kelepa yang dinobatkan sebagai Batara Walayut berkedudukan di Mandala Cidatar. Dia dijadikan pemerkokoh negeri, sebagai daerah kunci. Kewenangannya beristeri satu. "Apabila engkau berniat beristeri dua atau tiga dapat berdampak buruk, dikatakan tidak pantas..." (lembar nomor 10a-10b)
Bagawat Resi Kelepa dinobatkan sebagai Batara Walayut, yakni rama yang berkedudukan di Mandala Cidatar oleh Maharaja Trarusbawa. Disebutkan pula bahwa Mandala Cidatar adalah daerah kunci di wilayah Kerajaan Sunda. Beliau pun hanya bisa memperistri satu wanita, karena apabila beristri lebih dari satu, hal itu bukanlah sesuatu yang pantas untuk dilakukan.

Lalu, Maharaja Trarusbawa mengeluarkan sebuah kalimat yang berisi pelantikan Bagawat Cinta Putih untuk menduduki jabatan prebu di Gegergadung, yang kutipan teksnya terdapat di bawah ini:

...Tersebutlah kesepakatan para penerus seisi istana yang bernaung ke Pakuan. Sementara itu, Bagawat Cinta Puth dinobatkan sebagai Batara di Gegergadung. Dia menjiwai sifat mulia yang penuh tawakal, selang-selang tetap sekedar berdoa, bagaikan dunia dan raga tengadah, yang dijadikan harapan kehidupan suci, mengharap berkah kekayaan. Hendaklah jangan beristeri dua atau tiga karena dapat berdampak buruk sehingga dikatakan keadaan akan jadi kacau, khawatirnya dikatakan tidak pantas memiliki integritas. Sang Prebu selalu menyadari kekuasaan, baik yang besar maupun yang kecil. Demikianlah. (lembar nomor 10b2a)

Pada bagian teks ini, Bagawat Cinta Putih yang menjiwai sifat mulia yang penuh tawakal diangkat sebagai prebu di Gegergadung. Beliau juga hanya diperkenankan untuk beristri satu, karena apabila beristri lebih dari satu, bisa menyebabkan keadaan menjadi kacau dan menghilangkan integritas prebu yang beliau emban. Dikatakan pula bahwa salah satu sifat prebu yaitu selalu menyadari kekuasaan yang ia miliki, baik itu kekuasaan yang besar (kekuasaannya dalam menjalankan tugasnya sebagai pemimpin masyarakat) maupun kekuasaan yang kecil (kekuasaannya dalam mengendalikan dirinya sendiri).

Setelah pelantikan Bagawat Cinta Puth tersebut, Maharaja Trarusbawa kemudian mengangkat Bagawat Cinta Premana sebagai rama di Puntang. Berikut ini adalah kutipan teksnya:

Tersebutlah kesepakatan para penerus seisi istana yang bernaung ke Pakuan. Oleh 
Maharaja Trarusbawa, Bagawat Cinta Premana dinobatkan sebagai Sanghyang Premana di Puntang. Dari situlah permulaan apa yang harus diperbuat oleh yang berdaulat apabila sanggup memperkokoh hakikat alam kesejahteraan. Jagat diartikan sebagai buana. Tri Buana terdiri atas bumi, antara, dan angkasa; termasuk di dalamnya langit, rasi bintang, dan kilauan nebula (gugusan bintang) pada malam hari. Itulah sebabnya alam raya bernama demikian. Seandainya itu dipahami dan diamalkan para siswa, maka berarti akan sejahtera. Apabila kalian berniat mempersaudarakan dalam satu kerabat bermadu isteri saudara tua, memperbudak tanpa tebusan, menghukum tak berdasarkan aturan; maka khawatir dapat berakibat hancurnya negeri... (lembar nomor 2b-3a)

Pada bagian ini, Maharaja Trarusbawa memberikan kewenangan kepada Bagawat Cinta Premana menjadi rama di Puntang dengan gelar Sanghyang Premana. Beliau bertugas sebagai wakil rakyat yang membimbing masyarakat menuju kesejahteraan. Disebutkan bahwa apabila masyarakat mengerti akan hakikat kehidupan, maka kesejahteraan akan datang dengan sendirinya. Disebutkan pula bahwa bila para pemegang kekuasaan bermadu isteri saudara tua, memperbudak tanpa tebusan dan menghukum tak berdasarkan aturan, maka negeri akan hancur. Di dalam bagian teks ini disebutkan juga konsep Tri Buana.

Selepas melantik bagawat Cinta Premana menjadi rama di Puntang, Maharaja Trarusbawa lalu menyampaikan sebuah kalimat informatif yang berisi tentang pengangkatan Bagawat Tiga Warna sebagai rama di Mandala Pucung. Beliau bersama istrinya bertugas membimbing masyarakat menuju kesejahteraan. Berikut ini kutipan teksnya:

...Tersebutlah kesepakatan para penerus seisi istana yang bernaung ke Pakuan. Oleh Maharaja Trarusbawa, Bagawat Tiga Warna dinobatkan sebagai penebar anak (murid) di Mandala Pucung, diberi kewenangan bagi isterinya... (lembar nomor 3a)

Pada kalimat terakhir dari bagian teks lembar 25a-3b FCP ini, Maharaja Trarusbawa memberikan kewenangan kepada Bagawat Piturasa sebagai rama di Mandala Utama
Jangkar. Sebagaimana yang tertuang dalam kutipan teks berikut:

...Bagawat Piturasa dinobatkan sebagai Batara Sugih Warna di Mandala Utama Jangkar, diberi kewenangan isterinya merencanakan pelaksanaan persiapan didirikannya pintu gerbang, mengingat pada bekas Maharaja Trarusbawa bermukim dahulu keluar lewat gerbang istana itu. (lembar nomor 3a-3b)

Bagawat Piturasa dinobatkan sebagai Batara Sugih Warna di Mandala Utama Jangkar, di mana Mandala Utama Jangkar merupakan tempat keluarnya Maharaja Trarusbawa dari wilayah kerajaan. Mandala Utama Jangkar terletak pada batas terluar Kerajaan Sunda, di mana Maharaja Trarusbawa memberikan kewenangan pada istri dari Bagawat Piturasa untuk merencanakan pelaksanaan persiapan didirikannya pintu gerbang wilayah Kerajaan Sunda.

Jadi, konstruksi kalimat yang mengandung teks Tri Tangtu di Buana dalam Fragmen Carita Parahyangan (FCP) pada tahap pertama menunjukkan bahwa Tri Tangtu di Buana adalah tiga lembaga yang terdiri dari prebu, rama, dan resi. Prebu memegang urusan kekuatan, artinya prebu memiliki kekuasaan untuk menjalankan roda pemerintahan dan berperan pula sebagai penentu kebijakan. Dalam aktivitas komunikasi politik pembagian wilayah kekuasaan yang melibatkan Tri Tangtu di Buana, Maharaja Trarusbawa mengangkat Bagawat Sangkan Windu dan Bagawat Cinta Putih sebagai prebu di Denuh dan Gegergadung. Rama memegang urusan kata-kata, artinya rama adalah penyalur aspirasi dari rakyat pada pemimpin, sekaligus sebagai pembimbing untuk rakyat. Berkaitan dengan rama, Maharaja Trarusbawamengangkat Sang Resi Putih, Bagawat Resi Kelepa, Bagawat Cinta Premana, Bagawat Tiga Warna, dan Bagawat Piturasa sebagai rama di Galunggung, Mandala Cidatar, Puntang, Mandala Pucung, dan Mandala Utama Jangkar. Resi memegang urursan pikiran dan perasaan, artinya resi berperan sebagai "otak dan hati" kerajaan; di mana resi berperan besar untuk masalah peradilan demi mewujudkan negara yang adil, makmur, dan sentosa. Ketiga lembaga tersebut mengandung aspek-aspek komunikasi politik dalam peristiwa pembagian kekuasaan dan 
pembagian wilayah kekuasaan Kerajaan Sunda. Peristiwa pembagian kekuasaan tertuang dalam naskah $F C P$ lembar 7b-8a, sedangkan peristiwa pembagian wilayah kekuasaan tersurat dalam lembar 25a-3b.

Tahap kedua digunakan untuk mengungkap makna teks berdasarkan latar belakang pemroduksi teks. Tahap ini membahas tentang makna teks yang terkandung dalam pikiran dan pengalaman hidup sang pengarang teks. Pengarang teks $F C P$ diduga kuat adalah kaum intelektual pada saat masa pemerintahan Maharaja Trarusbawa. Teks diciptakan dengan tujuan sebagai sumber informasi mengenai pembagian kekuasaan dan pembagian wilayah kekuasaan pada masa sistem pemerintahan Kerajaan Sunda yang dilakukan Maharaja Trarusbawa dalam lingkup Tri Tangtu di Buana kepada perangkat kelembagaan yang dibangun pada saat itu, yakni prebu, rama dan resi.

Pemroduksi teks merekam peristiwa tersebut ketika peristiwa tersebut berlangsung. Selain sebagai sumber informasi, teks ini berperan sebagai "perekam" peristiwa yang terjadi pada saat itu. Sebagai kaum intelektual, pemroduksi teks berperan sebagai peneliti dan pencatat peristiwa-peristiwa yang terjadi dalam seluruh ruang lingkup masyarakat Sunda pada zaman kerajaan tersebut. Hal ini mengungkap sisi historis dari Tri Tangtu di Buana. Jadi, sisi historis dari Tri Tangtu di Buana juga tidak lepas dari aspek komunikasi politik; para pemroduksi teks membuat teks Tri Tangtu di Buana dalam naskah Fragmen Carita Parahyangan sebagai media komunikasi politik tradisional, baik itu sebagai sumber informasi politik kerajaan maupun sebagai "media" perekam aktivitas komunikasi politik Kerajaan Sunda (dari teks berbentuk perilaku politik menjadi teks tertulis) yang bisa diwariskan dari zaman ke zaman. Berkat adanya naskah Fragmen Carita Parahyangan yang memuat teks Tri Tangtu di Buana ini, sistem pemerintahan Kerajaan Sunda yang berpegang teguh pada pembagian kekuasaan prebu, rama, dan resi ini dapat menjalankan pemerintahannya dengan baik, harmonis, dan tanpa ada halangan berarti. Para aktor politik disebutkan secara jelas oleh para pemroduksi teks, pesan-pesan politik dalam aktivitas komunikasi politik dalam peristiwa pembagian kekuasaan dan pembagian wilayah kekuasaan juga disuratkan dengan jelas dalam naskah Fragmen Carita Parahyangan tersebut. Bisa dikatakan, makna yang syarat akan aspekaspek komunikasi politik dan terkandung dalam teks Tri Tangtu di Buana yang diproduksi oleh para pembuat teks yang merupakan kaum intelektual Kerajaan Sunda dapat diinterpretasi dengan baik oleh kaum elit Kerajaan Sunda dalam menjalankan pemerintahan dan konsep Tri Tangtu di Buana yang mereka emban. Tahap ketigaadalahmaknateks berdasarkanlingkungan teks. Tahap ini membahas tentang makna yang terkandung di tengah kelompok sasaran di mana sebuah teks dikomunikasikan. Teks ini dikomunikasikan di kalangan Kerajaan Sunda pada masa pemerintahan Maharaja Trarusbawa. Teks ini juga terdapat pada naskah $F C P$ yang di dalamnya memang membahas masalah-masalah politik, terutama yang terkait dengan konsep Tri Tangtu di Buana di Kerajaan Sunda pada masa pemerintahan Maharaja Trarusbawa. Teks tentang pembagian kekuasaan dan pembagian wilayah kekuasaan ini dikomunikasikan di kalangan elit pemegang kekuasaan Kerajaan Sunda, di mana masyarakat Sunda pada saat itu juga menilai kinerja para pemegang kekuasaan yang dituntun oleh bagian teks $F C P$ ini. Para pemegang kekuasaan Kerajaan Sunda (Tri Tangtu di Buana) menjadikan bagian teks $F C P$ ini sebagai panduan untuk menjalankan tugas dan wewenang sesuai dengan jabatan mereka masing-masing. Bagian-bagian teks ini juga memberikan informasi bahwa pada saat Kerajaan Sunda masih eksis, pembagian wilayah kekuasaan telah dilakukan dengan menempatkan orang-orang yang memiliki integritas di wilayah-wilayah kerajaan yang telah ditentukan. Undang Ahmad Darsa, filolog sekaligus penggarap naskah FCP, memberikan informasi sebagai berikut:

\footnotetext{
"Dinyatakan dalam teks FCP bahwa Maharaja Trarusbawa berusia 1100 tahun. Ini sulit untuk dipercaya dari sisi usia fisik hidup manusia, akan tetapi hal ini harus ditafsirkan justru konsep Tri Tangtu di Buana itulah yang berlaku selama 1100 tahun. Hal dimaksud diduga secara historis muncul setelah Kerajaan Tarumanagara tenggelam (abad ke-7 M) dan berakhir ketika sistem Kerajaan Sunda juga
} 
tenggelam (abad ke-16 M).”

Jadi, konsep Tri Tangtu di Buana ini mulai dijalankan di lingkungan elit Kerajaan Sunda mulai dari Kerajaan Sunda berdiri (setelah Kerajaan Tarumanagara tenggelam pada abad ke-7 M) hingga Kerajaan Sunda tenggelam pada abad ke-16 M. Dengan kata lain, teks Tri Tangtu di Buana yang banyak mengandung aspek komunikasi politik ini dikomunikasikan melalui naskah Fragmen Carita Parahyangan selama 9 abad lamanya.

Tahap keempat ditempuh untuk mengungkap makna teks berdasarkan kaitan dengan teks lain, yaitu makna yang diperoleh dengan cara mengkombinasikan makna yang terkandung baik yang terdapat dalam teks yang sama dalam satu naskah maupun dalam naskah yang berbeda. Terdapat kaitan yang kuat antara pembagian kekuasaan Tri Tangtu di Buana dalam naskah FCP pada lembar 7b-8a dengan teks pembagian kekuasaan pada lembar $4 b-5 a$ yang berisi tentang pembagian kekuasaan oleh Maharaja Trarusbawa kepada kalangan prebu, rama dan resi dalam menjalankan tugasnya. Berikut ini adalah kutipan teks $F C P$ lembar 4b-5a yang berisi tentang proses pembagian kekuasaan dalam Kerajaan Sunda yang melibatkan Tri Tangtu di Buana:

Anggeus pahi diduuman ku Maharaja Trarusbawa, diduuman deui jagat, saukur nu wenangkeun rabi tunggal. Na jagat kreta di sang resi dijiéunan lemah putih, lemah pasartan husireun wong kapanasan; jagat darana di sang rama; jagat palaka di sang prebu. Kéh mulah dék paala-ala, palungguhlungguhan. Haywa pamali pangmeunang dék paala-ala.

Terjemahan:

Setelah semua mendapat bagian dari Maharaja Trarusbawa, dibagi lagi tanggung jawab kekuasaan, untuk setiap yang diharuskan beristeri satu. Maka dunia kesentosaan tanggung jawab kalangan Resi yang dijadikan sebagai tempat suci, tempat mencari keadilan orang yang teraniaya. Dunia bimbingan tanggung jawab kalangan Rama. Dunia pemerintahan tanggung jawab kalangan Prebu. Nah janganlah saling berebut kedudukan. Hendaklah jangan khawatir saling berebut penghasilan (lembar nomor $4 \mathrm{~b}$ dan awal lembar 5a).

Teks bagian ini terdapat pada lembar nomor 4 b dan awal lembar 5a $F C P$ yang berisi tentang pembagian kekuasaan oleh Maharaja Trarusbawa kepada kalangan prebu, rama dan resi dalam menjalankan tugasnya. Pada saat itu sang Maharaja-lah yang memegang tampuk kepemimpinan pemerintahan Kerajaan Sunda. Maharaja juga adalah simbol kerajaan/negara. Dalam konsep kekuasaan, kekuasaan tertinggi dipegang oleh negara. Secara formal negara memiliki hak untuk melaksanakan kekuasaan tertinggi. Negara jualah yang membagi-bagikan kekuasaan yang lebih rendah derajatnya. Itulah yang dinamakan kedaulatan (sovereignity). Dalam hal ini, karena maharaja merupakan simbol dari Kerajaan Sunda, maka ia memiliki kedaulatan untuk menjalankan pemerintahan dan membagikan kekuasaan kepada orangorang yang telah ia percayai.

Kaitan kuat juga terjadi dalam teks Tri Tangtu di Buana dalam naskah FCP dengan Tri Tangtu di Buana dalam naskah Amanat Galunggung $(A G)$. Kedua bagian teks ini menyebutkan tentang pembagian kekuasaan prebu, rama dan resi dalam lingkup Tri Tangtu di Buana. Bagian yang persis sama terdapat pada bagian kalimat yang menyebutkan bahwa dunia bimbingan adalah tanggung jawab rama, dunia kesentosaan menjadi tanggung jawab resi, dan dunia pemerintahan menjadi tanggung jawab prebu. Sama halnya dengan kalimat yang menyebutkan bahwa dalam pekerjaanya sebagai pejabat, hendaknya kalangan prebu, rama dan resi tidak berebut penghasilan.

Hanya saja, pada bagian teks yang terdapat pada $A G$, bagian akhirnya juga menyebutkan hal-hal yang harus dilakukan untuk menjadi seorang pejabat yang mulia, dengan perbuatan, ucapan dan sifat-sifat yang terpuji. Dengan menjiwai sifat-sifat tersebut, niscaya para pemegang tampuk kekuasaan ini akan menjadi teladan masyarakat. Keterkaitan ini membentuk sebuah intertekstualitas, di mana esensi teks yang sama terkandung dalam dua naskah yang berbeda. Kaitan ini semakin menguatkan konsep Tri Tangtu di Buana sebagai sistem kelembagaan Kerajaan Sunda yang menganut pembagian/pemisahan kekuasaan dan memuat 
unsur-unsur politik yang kuat, yang di dalamnya juga terkandung aspek-aspek komunikasi politik. Aspek komunikasi politik yang terkandung di dalam kedua naskah ini berkaitan dengan aktor politik (Maharaja Trarusbawa) dan pesan-pesan politik yang berkaitan dengan pembagian kekuasaan dan sikap-sikap yang harus dimiliki oleh prebu, rama, dan resi dalam sistem pemerintahan Tri Tangtu di Buana.

Konsep Tri Tangtu di Buana ini berkaitan juga dengan konsep Tri Buana, yakni sebuah sistem kosmologis masyarakat Sunda berdasarkan konsep triumvirate (tiga serangkai, tritunggal) yang terdiri atas bumi, antara, dan angkasa; termasuk di dalamnya langit, rasi bintang, dan kilauan nebula (gugusan bintang) pada malam hari. Selain berkaitan dengan konsep Tri Buana, konsep Tri Tangtu di Buana ini juga berkaitan dengan konsep "Tiga Rahasia" yang tercantum dalam naskah Sang Hyang Hayu (SHH). Dalam naskah SHH, unsur prebu-ramaresi inilah yang mengemban tugas dalam upaya ngretakeun bumi lamba (mensejahterakan kehidupan di dunia). Berdasarkan konsep "Tiga Rahasia", berarti prebu harus menjiwai nilai bayu (tenaga), rama harus menjiwai nilai sabda (ucapan), dan resi harus menjiwai nilai hedap (pikiran/qalbu). Dengan kata lain, prebu mewakili bayu, rama mewakili sabda, dan resi mewakili hedap. Adanya konsep Tri Tangtu Di Buana, Tri Buana dan "Tiga Rahasia" ini menggambarkan bahwa konsep tata ruang masyarakat Sunda secara kosmologis selalu bersifat triumvirate.

Ternyata, setelah bayu-sabda-hedap ini diterapkan pada nilai yang harus dijiwai oleh prebu-rama-resi, terjadi kecocokan dengan bagian teks pada lembar 7b-8a FCP yang menyebutkan bahwa urusan kekuatan itu bagian kalangan prebu, urusan kata-kata itu bagian kalangan rama, dan urusan pikiran dan perasaan itu bagian kalangan resi. Hal ini membuktikan terjadinya intertekstualitas antara naskah FCP dengan naskah $S H H$ yang samasama membahas tentang konsep dan nilainilai yang terdapat dalam proses pembagian kekuasaan. Konsep "Tiga Rahasia” dalam $\mathrm{SHH}$ memperkaya konsep pembagian kekuasaan Tri Tangtu di Buana dalam FCP. Hal ini menyiratkan bahwa kekuasaan yang muncul dalam masyarakat Sunda kuno bersumber dari tradisi. Tradisi tersebut menjadi sebuah pijakan dan menghasilkan sebuah legitimate power bagi orang-orang yang memegang kekuasaan tertinggi. Mereka (prebu, rama, resi) menjalankan kekuasaan yang mereka miliki melalui saluran politik dan saluran tradisional. Melalui saluran politik, mereka mengkomunikasikan aturan-aturan yang harus ditaati oleh segenap pejabat dan rakyat Kerajaan Sunda. Melalui saluran tradisional, mereka mempertahankan nilai-nilai tradisi Sunda yang sudah tertanam beratus-ratus tahun lamanya dalam masyarakat.

Terkait dengan pembagian wilayah kekuasaan, terdapat kaitan yang kuat antara pembagian wilayah kekuasaan pada naskah $F C P$ lembar 25a-3b dengan teks pembagian wilayah kekuasaan pada lembar 8b-9b. Perbedaan yang lain adalah bila pada teks $F C P$ lembar 25a-3b proses pembagian wilayah kekuasaan dilakukan dengan melibatkan Maharaja Trarusbawa beserta kalangan prebu, rama, dan resi, serta dilakukan dalam sebuah forum komunikasi yang besar dan formal, pada teks lembar 8b$9 \mathrm{~b}$ ini proses pembagian wilayah kekuasaan hanya melibatkan dua orang, yakni Rakeyan Darmasiksa dan Batara Dangiang Guru. Berikut ini adalah kutipan teks $F C P$ lembar 8 b-9b yang berisi tentang proses pembagian wilayah kekuasaan:

Anggéus ta diéusikeun na Rakéan Darmasiksa na Sunggalah. Diheuleutan: Hanggat Cipanglebakan, alas ti kidul heuleutna Gegergadung, Geger Handiwung, Pasir Taritih na muhara Cipager Jampang. Heuleutna ti Windupepet Manglayang Padabeunghar. Sakitu dibéréan alas Rakéan Darmasiksa ku Batara Danghyang Guru di Galunggung. Heubeul siya ngadeg di Saunggalah dwa welas tahun, deung anak Sang Rajaputra dieusikeun di Saunggalah.

Terjemahan:

Selesailah Rakeyan Darmasiksa tersebut diperkenankan menduduki Saunggalah. Batas wilayahnya: tepi sungai Cipanglebakan; wilayah sebelah selatan berbatasan dengan Gegergadung dan Geger Handiwung terus ke Pasir Taritih hingga ke muara Cipager Jampang; sedangkan batas wilayah dengan Windupepet ialah Manglayang dan Padabeunghar. 
Seluas itulah wilayah yang diberikan kepada Rakeyan Darmasiksa oleh Batara Dangiang Guru di Galunggung. Lamanya dia menjabat di Saunggalah ialah dua belas tahun, dan anaknya yang bernama Sang Rajaputra kemudian ditempatkan di Saunggalah (lembar nomor $8 b$ dan lembar nomor $9 b$ ).

Dalam bagian teks ini, Batara Dangiang Guru berperan sebagai komunikator yang menyampaikan pesan politik kepada komunikannya, yakni Rakeyan Darmasiksa yang diberikan kewenangan untuk menjadi prebu di Saunggalah dengan batas-batas wilayah yang telah ditentukan. Komunikasi ini berlangsung secara face-to-face, di mana Batara Dangiang Guru menyampaikan pesannya secara langsung kepada Rakeyan Darmasiksa. Pola komunikasi politik antara atara Dangiang Guru dengan Rakeyan Darmasiksa adalah pola komunikasi informal dalam konteks komunikasi antar pribadi, karena dilakukan melalui sebuah pertemuan yang di dalamnya tidak terdapat prosedur-prosedur formal layaknya pada proses pembagian kekuasaan yang telah dibahas pada bahasan sebelumnya.

Perbedaan yang lain adalah bila pada teks $F C P$ lembar $25 \mathrm{a}-3 \mathrm{~b}$ proses pembagian wilayah kekuasaan dilakukan dengan melibatkan Maharaja Trarusbawa beserta kalangan prebu, rama, dan resi, serta dilakukan dalam sebuah forum komunikasi yang besar dan formal, pada teks lembar 8b-9b ini proses pembagian wilayah kekuasaan hanya melibatkan dua orang, yakni Rakeyan Darmasiksa dan Batara Dangiang Guru. Seperti yang telah dikemukakan di atas, komunikasi politik adalah komunikasi yang pesannya berisi tentang kelangsungan hidup suatu negara/pemerintahan. Maka, pemberian kewenangan Rakeyan Darmasiksa untuk memimpin Saunggalah oleh Batara Dangiang Guru juga mengandung aspek komunikasi politik yang terwujud dalam aktivitas komunikasi politik.

Bagian terakhir ditempuh untuk mengungkap makna teks berdasarkan dialog teks dengan pembaca. Tahap ini membahas tentang makna yang timbul setelah pembaca teks juga memasukkan makna yang ada dalam pikirannya setelah membaca sebuah teks. Teks FCP ini mengandung aspek-aspek komunikasi politik yang terwujud dalam aktivitas komunikasi politik yang dilakukan dalam lingkup kelembagaan Tri Tangtu di Buana yang dilakukan oleh Maharaja Trarusbawa dengan segenap pejabat di Kerajaan Sunda. Komunikasi politik yang dilakukan bersifat face-to-face dalam sebuah forum komunikasi "satukepada-banyak" dalam tatanan suprastruktur komunikasi Kerajaan Sunda.

Maharaja Trarusbawa berperan sebagai komunikator politik yang menyampaikan pesan-pesan politiknya kepada para komunikan politiknya, dalam hal ini para prebu, rama dan resi yang berada dalam tataran suprastruktur komunikasi politik Kerajaan Sunda. Maharaja Trarusbawa memiliki kekuasaan yang sah (legitimate power) yang memiliki hak untuk membagikan kekuasaannya melalui aktivitas komunikasi politik. Beliau juga memiliki persyaratan yang memadai untuk menjadi komunikator politik, yakni berorientasi kepada kepentingan negara (Kerajaan Sunda).

Maharaja Trarusbawa sebagai komunikator politik memiliki dominasi yang bersumber dari legitimate power. Legitimate power yang beliau miliki memungkinkan beliau menyampaikan pesan komunikasi politik vertikal top-down. Bersumber dari kedudukannya sebagai Maharaja yang memiliki kewenangan sebagai pemegang dunia pemerintahan, beliau juga memiliki kemampuan untuk memerintah (agar yang diperintah patuh) dan juga untuk memberi keputusan-keputusan yang secara langsung maupun tidak langsung memengaruhi tindakantindakan pihak-pihak lainnya.

Pesan yang terdapat pada naskah $F C P$ lembar 7b-8a berisi tentang pembagian/ pemisahan kekuasaan dan tanggung jawab yang dipikul oleh prebu, rama, dan resi. Pesan politik yang disampaikan Maharaja Trarusbawa tentang pembagian kekuasaan ini termasuk ke dalam sejumlah metode dan cara pendekatan untuk mewujudkan sifat-sifat integratif bagi penghuni sistem. Komunikasi politik yang dilakukan bersifat face-to-face dalam tatanan suprastruktur komunikasi Kerajaan Sunda. Beliau menyampaikan pesan politiknya kepada para komunikan dalam sebuah forum komunikasi "satu-kepada-banyak" tentang pembagian kewenangan dan tugas dari kalangan prebu, rama, dan resi sehingga para pemangku jabatan tersebut mengerti apa tugas yang harus 
mereka laksanakan dan sampai di mana mereka bisa berperan dalam sistem pemerintahan. Bentuk pesan politik yang disampaikan Maharaja Trarusbawa kepada kalangan prebu, rama, dan resi ini berupa keputusan, kebijakan, dan peraturan yang menyangkut kepentingan dari keseluruhan masyarakat, bangsa, dan negara.

Ditambah pula, terdapat pesan bahwa para pejabat kerajaan tersebut haruslah beristri satu, karena apabila beristri lebih dari satu, dikhawatirkan akan mengganggu konsentrasi dalam menjalankan aturan-aturan pemerintahan sehingga dapat berakibat terganggunya kesentosaan dan kesejahteraan masyarakat. Hal ini merupakan sebuah panduan dan nilai-nilai idealis yang tertuju pada upaya mempertahankan dan melestarikan sistem nilai yang berlangsung. Media yang beliau pergunakan berupa sebuah forum komunikasi "satu-kepada-banyak" yang dihadiri oleh perwakilan prebu, rama dan resi.

Pembicaraan politik yang dilakukan dalam tatanan suprastruktur komunikasi tersebut, tentu saja pesan yang disampaikan oleh Maharaja Trarusbawa kepada kalangan prebu, rama, dan resi adalah pesan komunikasi politik, karena pesan tersebut disampaikan oleh pemegang kekuasaan tertinggi pada sebuah pemerintahan, dan pesannya sendiri mengandung nilainilai idealis yang tertuju kepada upaya mempertahankan dan melestarikan sistem nilai yang sedang berlangsung dalam sebuah negara, dalam hal ini Kerajaan Sunda.

Selain itu, konsep Tri Tangtu di Buana dalam tatanan suprastruktur Kerajaan Sunda tidak terlepas pada sistem kosmologis Sunda yang menganut konsep triumvirate yang artinya tiga serangkai/tritunggal (bumi, antara, angkasa). Maka dapat disimpulkan bahwa tradisi Sunda yang berangkat dari sistem kosmologis triumvirate ini juga memengaruhi sistem legitimasi di Kerajaan Sunda. Otomatis, sistem legitimasi ini juga memengaruhi komunikasi politik yang terjadi dalam tatanan suprastruktur Kerajaan Sunda. Pada akhirnya, komunikasi politik masyarakat Sunda kuno dalam FCP yang kental dengan konsep Tri Tangtu di Buana ini dilakukan dengan berpegang pada tradisi yang telah dianut sejak awal Kerajaan Sunda berdiri.

Aktivitas komunikasi politik yang terjadi ada di dalam tatanan suprastruktur, di mana Maharaja Trarusbawa sebagai komunikator politik melakukan pembagian/pemisahan kekuasaan kepada kalangan prebu, rama dan resi dengan pola komunikasi top-down, dari pemimpin kepada yang memimpin. Hal tersebut tampak jelas dalam titah Maharaja Trarusbawa yang disampaikan langsung melalui sebuah forum komunikasi kepada para perwakilan pejabat Kerajaan Sunda, di mana pesan politik yang disampaikan adalah tentang pembagian/ pemisahan kekuasaan.

Terkait dengan pembagian wilayah kekuasaan di Kerajaan Sunda, Maharaja Trarusbawa membagikan wilayah kekuasaan Kerajaan Sunda kepada para pejabat daerah karena beliau memiliki kedaulatan (sovereignity) dan juga memang menjadi tugas beliau untuk menjalankan tanggung jawab di dunia pemerintahan, sesuai dengan tugas seorang prebu dalam konsep Tri Tangu di Buana. Maharaja Trarusbawa juga merupakan simbol Kerajaan Sunda. Dengan kata lain, Maharaja Trarusbawa memiliki kekuasaan tertinggi dalam dunia pemerintahan, karena berdasarkan konsep kekuasaan, secara formal, negara memiliki hak untuk melaksanakan kekuasaan tertinggi. Negara jualah yang membagi-bagikan kekuasaan yang lebih rendah derajatnya. Itulah yang dinamakan kedaulatan (sovereignity) (Soekanto, 2006: 31).

Aktivitas komunikasi politik yang dilakukan oleh Maharaja Trarusbawa berpola top-down dan dilakukan dalam sebuah forum komunikasi antara pemerintah pusat dengan para pejabat daerah. Komunikasi politik dalam forum komunikasi ini bersifat formal, karena dilakukan dalam konteks pembagian wilayah kekuasaan, di mana komunikan yang hadir juga merupakan orang-orang penting di Kerajaan Sunda. Saluran komunikasi politik yang dipakai adalah gabungan komunikasi "satu-kepadasatu" dan "satu-kepada-banyak".

Komunikasi politik pembagian wilayah kekuasaan yang dilakukan oleh Maharaja Trarusbawa pada teks lembar 25$3 \mathrm{~b}$ berorientasi kepada kepentingan negara (kerajaan) berisi panduan dan nilai-nilai idealis yang tertuju kepada upaya mempertahankan dan melestarikan sistem nilai yang sedang berlangsung dan bertujuan untuk mewujudkan 
sifat-sifat integratif bagi penghuni sistem. Pesanpesan komunikasi politik yang disampaikan oleh Maharaja Trarusbawa merupakan sebuah produk penguasa setelah melalui proses encoding atau setelah diformulasi ke dalam simbol-simbol sesuai lingkup kekuasaannya (Harun \& Sumarno, 2006: 12).

Teks pada lembar 25-3b jelas berisi tentang aktivitas komunikasi politik dalam tatanan suprastruktur komunikasi yang dilakukan oleh Maharaja Trarusbawa dengan segenap orang yang beliau percayai memiliki integritas untuk ditempatkan sebagai pejabat di wilayahwilayah Kerajaan Sunda yang telah ditentukan. Maharaja Trarusbawa sebagai komunikator memberikan kewenangan kepada para komunikannya yakni Sang Resi Putih, Bagawat Sangkan Windu, Bagawat Cinta Kelepa, Bagawat Cinta Putih, Bagawat Resi Karangan, Bagawat Cinta Premana, Bagawat Tiga Warna, dan Bagawat Pitu Rasa untuk memegang jabatan di wilayahnya masing-masing.

Sedangkan teks pada lembar 8b-9b berisi tentang komunikasi politik dalam pembagian wilayah kekuasaan yang melibatkan calon penerus Maharaja Trarusbawa, yaitu Rakeyan Darmasiksa dengan Batara Dangiang Guru yang berperan sebagai kalangan rama. Rakeyan Darmasksa diserahi sebuah tanggung jawab untuk menduduki kursi prebu di Saunggalah. Dengan diperolehnya wilayah kekuasaan yang merupakan hak milik kebendaan, otomatis Rakeyan Darmasiksa juga memiliki kekuasaan yang bersumber dari hak milik kebendaan atas wilayah Saunggalah. Dengan begitu, beliau juga memilki sumber kekuasaan politik, yang berguna untuk proses pengambilan keputusan yang berkaitan dengan dunia pemerintahan (sebagaimana memang menjadi tugas yang diemban seorang prebu dalam konsep Tri Tangtu Di Buana) di wilayah Saunggalah.

Berdasarkan paparan di atas, ditemukan Maharaja Trarusbawa menyampaikan penjelasannya tentang pembagian/pemisahan kewenangan dan tugas dari masing-masing prebu, rama dan resi, sehingga para pemangku jabatan tersebut mengerti apa tugas yang harus mereka laksanakan dan sampai di mana mereka bisa berperan dalam pemerintahan (lembar nomor 7 b dan awal lembar 8a). Dalam pembicaraan politik yang dilakukan dalam tatanan suprastruktur komunikasi tersebut (Tri Tangtu di Buana), tentu saja pesan yang disampaikan oleh Maharaja Trarusbawa kepada kalangan prebu, rama dan resi adalah pesan komunikasi politik, karena pesan tersebut disampaikan oleh pemegang kekuasaan tertinggi pada sebuah pemerintahan, dan pesannya sendiri mengandung nilai-nilai idealis yang tertuju kepada upaya mempertahankan dan melestarikan sistem nilai yang sedang berlangsung dalam sebuah negara, dalam hal ini Kerajaan Sunda. Selain berisi tentang pembagian kekuasaan dalam lingkup Tri Tangtu di Buana, teks FCP ini juga berisi tentang aktivitas komunikasi politik yang dilakukan oleh Maharaja Trarusbawa sebagai prebu dalam Tri Tangtu di Buana dengan segenap orang yang beliau percayai memiliki integritas untuk ditempatkan sebagai pejabat di wilayah-wilayah Kerajaan Sunda yang telah ditentukan. Maharaja Trarusbawa memberikan kewenangan kepada Sang Resi Putih, Bagawat Sangkan Windu, Bagawat Cinta Kelepa, Bagawat Cinta Putih, Bagawat Resi Karangan, Bagawat Cinta Premana, Bagawat Tiga Warna, dan Bagawat Pitu Rasa untuk memerintah di wilayahnya masing-masing. Komunikasi politik yang dilakukan oleh Maharaja Trarusbawa berorientasi kepada kepentingan negara (kerajaan) berisi pesan-pesan politik yang bertujuan untuk kesejahteraan Kerajaan Sunda.

\section{SIMPULAN}

Setelah membaca dan menghayati teks dalam FCP ini, makna yang didapatkan oleh peneliti adalah Tri Tangtu di Buana yang terdiri dari prebu, rama, dan resi ini merupakan tiga lembaga yang secara bersamaan memegang jabatan di pemerintahan Kerajaan Sunda; di mana ketiganya memiliki hak dan kewajiban yang berbeda dalam memimpin Kerajaan Sunda. Pada peristiwa pembagian kekuasaan, aspek komunikasi politik yang terwujud dalam aktivitas komunikasi politik yang dilakukan oleh Maharaja Trarusbawa dengan segenap pejabat di Kerajaan Sunda dan bersifat face-toface dalam tatanan suprastruktur komunikasi Kerajaan Sunda. Komunikasi politik yang dilakukan oleh Maharaja Trarusbawa berpola top-down dan dilakukan dalam sebuah forum 
komunikasi antara pemerintah pusat dengan para calon pejabat daerah di wilayah Kerajaan Sunda. Sedangkan pada peristiwa pembagian wilayah kekuasaan, aktivitas komunikasi politik terkandung dalam peristiwa yang melibatkan Maharaja Trarusbawa sebagai komunikator politik yang menyampaikan pesan-pesan politik berupa pembagian wilayah kekuasaan kepada kalangan prebu, rama, dan resi selaku pemegang kekuasaan di wilayah-wilayah Kerajaan Sunda. Komunikasi politik yang dilakukan oleh Maharaja Trarusbawa berpola top-down dan dilakukan dalam sebuah forum komunikasi antara pemerintah pusat dengan para calon pejabat daerah. Selain itu, terdapat juga komunikasi politik pembagian wilayah kekuasaan antara Batara Dangiang Guru dengan Rakeyan Darmasiksa yang bersifat face-to-face.

Saran yang penulis berikan berdasarkan penelitian ini adalah perlu dikembangkannya penelitian lanjutan terhadap berbagai naskah Sunda Kuno khususnya dan naskah-naskah kuno Indonesia lain pada umumnya, karena di dalam naskah-naskah kuno ini terdapat banyak informasi dari berbagai bidang kajian yang dapat kita gali, serta perlunya penelitian komunikasi politik tradisional untuk memperluas khazanah ilmu komunikasi, khususnya komunikasi politik. Saat ini telah banyak penelitian yang mengangkat tema komunikasi politik mutakhir, tetapi penelitian yang bertemakan komunikasi politik tradisional masih amat langka.

\section{DAFTAR PUSTAKA}

Darsa, U. A., dkk. (2000). Tinjauan Filologis Terhadap Fragmen Carita Parahyangan: Naskah Sunda Kuno Abad XVI Tentang
Gambaran Sistem Pemerintahan Masyarakat Sunda. Sosiohumaniora 2: 57-63.

Endraswara, S. (2008). Metodologi penelitian sastra: epistemologi, model, teori, dan aplikasi. Yogyakarta: MedPress.

Harun, R. \& Sumarno AP. (2006). Komunikasi politik sebagai suatu pengantar. Bandung: Mandar Maju.

Hoed, B. H. (2011). Semiotik dan dinamika sosial budaya: ferdinand de saussure, roland barthes, julia kristeva, jacques derrida, charles sanders peirce, marcel danesi \& paul perron, dll. Jakarta: Komunitas Bambu.

Kuswarno, E. (2008). Etnografi komunikasi: suatu pengantar dan contoh penelitiannya. Bandung: Widya Padjadjaran.

Littlejohn, S. W. \& Karen A. Foss. (2009). Theories of human communication, $9^{\text {th }} \mathrm{ed}$. Jakarta: Salemba Humanika.

Mulyana, D. (2007). Ilmu komunikasi: suatu pengantar. Bandung: PT. Remaja Rosdakarya.

Poespoprodjo, W. (2004). Hermeneutika. Bandung: Pustaka Setia.

Raharjo, M. (2008). Dasar-dasar hermeneutika: antara intensionalisme dan gadamerian. Yogyakarta: Ar-Ruzz Media.

Ratna, N. K. (2009). Teori, metode, dan teknik penelitian sastra. Yogyakarta: Pustaka Pelajar.

Ricoeur, P. (1976). Interpretation theory: discouse and the surplus of meaning. Fortworth: Christian University of Texas Press.

Soekanto, S. (2006). Sosiologi: suatu pengantar. Jakarta: Raja Grafindo Persada.

Sumaryono, E. (1999). Hermeneutik: sebuah metode filsafat. Yogyakarta: Kanisisus. 